UNIVERSITY OF CALIFORNIA

COLLEGE OF AGRICULTURE

BERKELEY, CALIFORNIA
AGRICULTURAL EXPERIMENT STATION

E, W. HILGARD, DIRECTOR

CIRCULAR No. 14.

(MARCH, 1905.)

\title{
Practical Suggestions for Codling-Moth Control in the Pajaro Valley.
}

BY W. H. VOLCK.

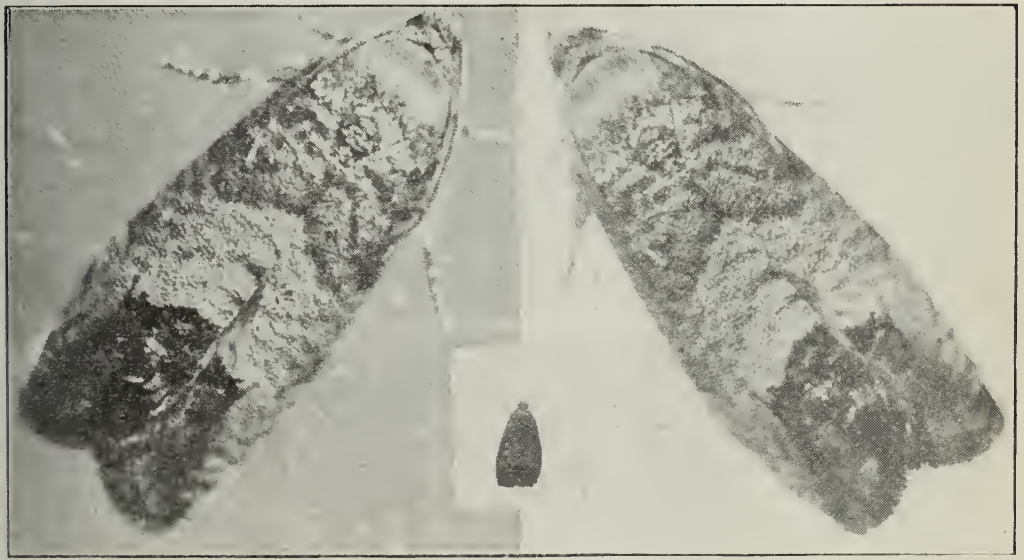

The Confx(;-Мoth. (Smallest figure shows natural size.)

Introductory Note.-There were two chief problems presented for solution in the study of the codling-moth in the Pajaro Valley, viz: first, the frequent failure to obtain sufficient control; and second, the very common serious injury to foliage by the material used. The answer to the first is that there were too few applications and these not properly timed to secure the best results. This matter is fully discussed in Bulletin No. 155. At the time of the publication of that bulletin the second problem was not satisfactorily answered. During the past season and the latter part of the preceding year, $\mathrm{Mr}_{\mathrm{r}}$. Tolck has been detailed to make a special study of this subject, and while he is not ret ready to give his results in full, still sufficient progress has been made to justify definite recommendations for the coming season's work. While the present circular is written particularly for the conditions obtaining in the Pajaro Valley, there is much that may be useful to 
growers of apples and pears in other sections where the danger from burning the foliage is small, in which case paris green is the most satisfactory spraying material.

C. W. WOODWORTH.

In this circular we will not attempt to give technical details further than necessary to make intelligible the practical suggestions herein contained.

The climatic conditions are such that, in the greater part of the Pajaro Valley, paris green can not be considered a safe insecticide. The fact that it has proven unsafe in this locality was a matter of common observation and experience with the orchardists of the valley for some years before the Codling-Moth Investigation was undertaken. However, as much adulterated and poorly-made paris green was on the market in this State at that time, the injury was attributed to these fraudulent products and the true cause was overlooked. It was with this idea that the investigation was undertaken in the spring of 1903.

The object of the early work was to show that the codling-moth could be controlled by arsenicals applied as a spray; and, as the standard arsenical was paris green, the greatest stress was laid on its use. The reliability of pure paris green was regarded as so certain that extensive spraying operations were undertaken with it.

Samples of all the paris green used in this spraying work were analyzed, and no material was applied which did not come within the requirements of the State law regarding the amount of free arsenious oxid and the total arsenic contained therein. Likewise, the most approved methods were practiced in the preparation and application of the spray.

With the careful selection of material and careful methods of application, it would seem that injuries resulting from errors or impurities must be nearly, if not wholly, eliminated. The marked injury which was experienced in several cases could not, therefore, be attributed to such causes, and it naturally devolved on the investigation to determine the factors productive of such results.

By washing paris green, taken from a guaranteed sample, for several days, an article practically free from uncombined arsenious oxid was obtained. Plants treated with this prepared green were injured quite as rapidly and severely as those treated with the unwashed samples. However, if the plants were protected by cloth coverings from the action of the fog and dew, it was found that no injury resulted.

Such laboratory experiments, together with the results obtained from the field work, led to the conclusion that the excessive moisture precipitation, in the form of fogs and dews, was the principal cause of the decomposition and solution of arsenicals, and, together with 
certain contributory conditions, brought about either the acute poisoning of the plant known as "burning," or the chronic form, resulting in the dropping of the leaves. Among these contributory causes of injury, the peculiar susceptibility of the Yellow Newtown Pippin variety of apple might take first rank. Had these trees been as resistant to arsenical poisoning as many of the other varieties found scattered through the orchards, little or no trouble would have been experienced. The Yellow Newtown Pippin is naturally delicate, and is rendered still more so by its susceptibility to the attacks of mildew. From these causes the apples in a considerable portion of the valley are not more resistant to paris green than peach trees, and even the reduced doses recommended for use on peaches are not wholly unattended by injury to the apple.

Thus it is apparent that the control of the codling-moth in such a locality is a more difficult problem than is generally encountered. As the amount of poison necessary to kill the young larva of the codlingmoth is relatively large, it became necessary either to so treat the paris green as to render it less affected by the weather, or to discard it in favor of some more stable arsenical.

Both of these methods of preventing injury were followed out in detail by carefully conducted experiments. In the first method most progress was made by treating paris green with heavy oils, which in combination with lime tended to form a weather-proof coating over the particles of the poison. The coating ultimately breaks down, however, under the very severe conditions of the Pajaro Valley and can not be considered a thorough success. The simple use of large quantities of lime accomplishes in the end almost the same result. This expedient is practiced with sucess in many apple regions and to some extent in the Pajaro Valley. The search for more stable compounds of arsenic met with better success, for it was soon found that lead arsenate possessed weather-resisting properties to a marked degree. Indeed, the commercial brands were found so resistant to weather decomposition that they caused little or no injury when used in the greatest excess.

THE CONTROL OF THE CODIING-MOTH WITH LEAD ARSENATE.

Having determined the behavior of lead arsenate toward foliage, it became necessary to learn to what extent the codling-moth might be controlled by it. Lead arsenate, as an insecticide, originated with the Gypsy Moth Commission in Massachusetts, and it was reported as more effective than paris green against the leaf-eating larvæ of the gypsy moth, possibly because a greater amount of poison could be 
applied without injuring the foliage. Thus the caterpillars could be poisoned by eating a smaller leaf surface than was possible with paris green.

Eastern experiment station work also indicates that lead arsenate is an efficient remedy for the codling-moth. The results at Watsonville were at first somewhat contradictory, but it developed from later work that the sample of lead arsenate used at that time was not a typical one. Later experiments indicate that a control equaling that of the best paris-green work might be obtained, but it is equally true that, weight for weight, the arsenic in paris green is the most effective. Hence, in using lead arsenate a much larger quantity of the poison must be applied.

In the first year's experiments the Kedzie mixture gave promise of results, but, during last season, the orchard treated most carefully the year before showed a greater amount of poisoning than was desirable, and it is feared that a continued use of the mixture will result in an accumulative effect, which may prove ultimately disastrous to the orchard. The unsafe nature of the Kedzie mixture (lime arsenite) was also demonstrated by numerous small experiments and by chemical tests of leaves which had been sprayed according to the standard formula. So while very cheap and somewhat less injurious than paris green, this mixture is not sufficiently weather-resistant to be recommended for use in the Watsonville district.

The Taft formula, which produces practically the same results as the Kedzie mixture, being also lime arsenite, is another arsenical which has given good results in many other sections, but will not answer here any better than the former. Experiments with other arsenicals were still less satisfactory, except the lead compounds of arsenic. These come under two principal groups, the arsenites and the arsenates, and of these lead arsenite was found to be so liable to injure the plant that it was never seriously considered. Lead arsenate, on the other hand, has proved the most stable of all the arsenicals. So much so, in fact, as to render it safe at practically any strength.

The so-called home-made arsenate of lead is a compound produced by combining a lead salt with a salt of arsenic acid, and may be prepared by the grower at the time of use. In the experiments on the home-made article conducted by the investigation, the formulas recognized by the Eastern experiment station were used, but in no case was an article produced which equaled the commercial brands with regard to foliage neutrality. By carefully washing some home-made samples in several changes of water, an article closely approximating the commercial lead was obtained, but still there was a noticeable difference.

Some Yellow Newtown Pippin trees were treated with home-made 
Iead arsenate throughout the season without injury to the foliage, but as it is desirable to use, for the control of the codling-moth, a greater concentration than that experimented with, it is hardly possible to generalize from this test.

Considerable difference was noticed in the lead arsenate samples experimented with, both in their killing power and in their behavior toward foliage. Of the two commercial brands, Disparene proved to be the safest, as no concentration was found which would injure the foliage of the most delicate plants. It was, however, less effective as a poison than the brand known as Swift's Arsenate of Lead. The maximum concentration of this arsenate slightly injured peach foliage after a considerable time, but this slight tendency to injure is not considered of any consequence in the practical treatment of apples to control the codling-moth. The killing power of Swift's Arsenate of Lead was found equal to that of the home-made arsenate.

It would then seem that the Pajaro Valley orchardist is driven to the use of one of the commercial brands of lead arsenate for immediate relief from the codling-moth next season. "Disparene" is a lead arsenate produced by the Bowker Insecticide Company of New York. According to the analysis published in Bulletin No. 151 of the California Experiment Station, Disparene was found to contain:

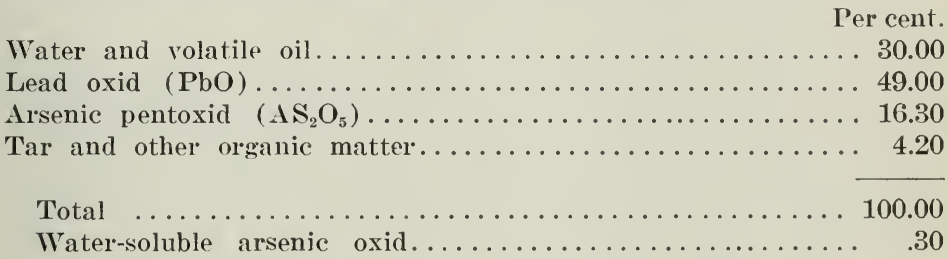

From an analysis published in the same bulletin, Swift's Arsenate of Lead was found to contain:

Per cent.

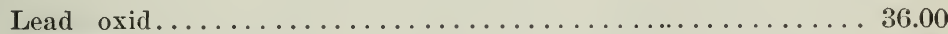

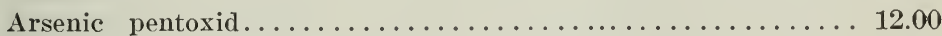

Organic matter (Glucose) and other organic matter....... 9.00

Water ............................... 43.00

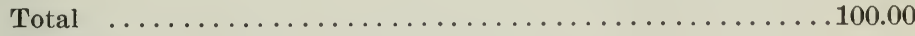

Water-soluble arsenic oxid.................... 15

It should be understood, however, that the above statements of ingredients pertain only to the samples analyzed, and as there is no State law controlling arsenicals other than paris green, the purchaser has only the good faith of the manufacturer to depend on concerning the uniformity of the product. He may, however, obtain more definite information by having samples out of every lot purchased, analyzed 
by the chemist of this Experiment Station. As such a procedure would involve much delay to the individual grower, the Codling-Moth Investigation is planning to keep track of the commercial arsenicals on the Watsonville market during the next season.

With the above-mentioned difficulty in mind it is to be deplored that the manufacture of home-made lead arsenate has not proven more practical. Realizing, however, that the needs of the Pajaro Valley orchardists are most urgent for an insecticide to be used during the coming season, it is recommended that commercial arsenate of lead be substituted for paris green. The experiments made last season show Swift's Arsenate of Lead to be the most satisfactory brand, and is therefore recommended, providing our tests this season correspond to those given above.

\section{THE CONTROL OF THE CODLING-MOTH.}

While the selection of an insecticide adapted to these local conditions is of prime importance, it is only through the proper application of this insecticide that satisfactory results are to be obtained. The subject of spraying to control the codling-moth may well be treated under two heads: the method of application of the spray, and the timing of the applications.

Methods of Spraying.-Our observations of the methods of spraying as the work is actually done in the Watsonville district has led us to the conviction that more thorough work is desirable in nearly every case. As ordinarily practiced, arsenical spraying is of a very superficial sort. Practically all of the spray is applied from outside. This method is thoroughly satisfactory for the first spraying, if the whole top of the tree is treated, as it serves to fill the blossom cups very well; but as the apples grow larger, an ever increasing amount of their surface is not wet by the spray. Likewise the leaves which cluster about the stem end are not sufficiently wetted, affording a protection for young codling worms and other Tortricid larvæ, both from the weather and the insecticide. The large number of late worms that attack the apples under such protection indicates the importance of this matter. Indeed, after August the codling worm is to some extent migratory, and may inflict damage on several apples, always working under such protection.

Thorough Spraying.-With these facts in mind it will be well to give the trees the benefit of thorough undershot and overshot sprayings, with the possible exception of the first two applications. The practice of more thorough methods in spraying will not be an innova- 
tion, as in many other sections where the control of the codling-moth has been an entire success the apples are so completely covered with lime that it would seem impossible for a worm to enter without burrowing through the coating.

The Timing and Number of Sprayings.-Throughout the Pajaro Valley the codling-moth inflicts the greatest damage during the late summer and fall. This fact has led many to believe that the late sprayings are the most important, and that the earlier ones might be neglected. The fall infestations are due evidently to the moths which have developed from the spring generation of worms, and the early sprayings are to reduce the quantity of moths whose progeny make the later attacks. There are very few localities where the spring and early summer sprayings are not of equal or greater importance in the actual control-work than the late sprayings. "The control which may be obtained through spraying is materially influenced by the number of eggs laid, for in any event only a certain percentage of the worms will be killed. Hence the value of the early sprayings lies not so much in the worms killed at the time, but in reducing the number of eggs to be laid later.

While spraying must be prastically continuous, still it is true that there are times when little or no egg-laying is in progress. During last season such a lull occurred in June and the early part of July, but there was much local variation. Such variation made it impossible to outline any general statement as to the time of occurrence or duration of the broods of moths. Again, the difference in seasons may so change these periods as to make any forecast of them absurd. The only way in which the lulls in egg-laying may be used to advantage in reducing the expense of spraying is to place breeding-cages, stocked with pupæ, in the orchards and observe the time of emergence of the moths, as was recommended in Bulletin No. 155 of this Station. This is not too difficult a matter for the average grower to undertake, but we do not expect that many will adopt it before the saving effect has been demonstrated in a number of orchards. To make such demonstrations will be a very important part of the work of the CodlingMoth Investigation during the next season.

In the meantime, when the periods of egg-laying are not accurately known, the only safe way is to assume that the orchard needs spraying at regular intervals from the falling of the blossoms to the picking of the fruit. The intervals between sprayings should not be too great, for while the leaves hold the poison very tenaciously, and tend to accumulate a larger amount as the season advances, the fruit is subject to loss through its rapid growth and the consequent scaling off 
of the arsenical. Also, the growth of the apple develops a new surface which must be covered with poison. All things considered, the time between sprayings need not be materially less than three weeks, and should not be greater than one month.

The following programme applies to the Pajaro Valley:

The First Spraying. - The first spraying with arsenate of lead should be applied as soon as the first blossoms have fallen. Owing to the variations in seasons it is not possible to fix an exact date, but this will be about April 10th. Do not wait for all the blossoms to fall, as this may delay the operation until the blossom ends of the majority of the young apples have closed. At this spraying the use of a large amount of material will be advisable, $i$. e., 3 pounds to 50 gallons of water. Fear of rains need not delay the operation, as lead arsenate sticks much better to the foliage than paris green and there is no danger from water-soluble arsenic.*

The Second Spraying.-About the 30th of April the orchard should receive another spraying. At this application spray thoroughly both upper and under side of the leaves, but with as little drip as possible. Use 2 pounds of lead arsenate to 50 gallons of water.

The Third Spraying.-This spraying should be applied about the 17th of May. A concentration of $11 / 2$ pounds of lead arsenate to 50 gallons of water should be sufficient. The spraying should include

\footnotetext{
*While lead arsenate is a very great improvement over paris green in the matter of retention or rain resistance, it may be improved in this respect by adding some adhesive. The resin-soap adhesive has given excellent results in the East. It is prepared according to the following formula:

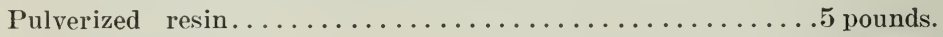

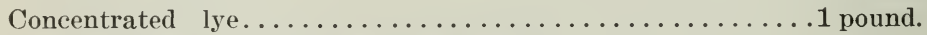

Fish, or other animal oil (except tallow) ...........

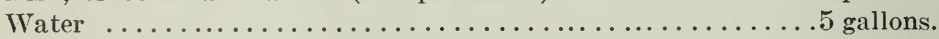

Place the oil, resin, and one gallon of hot water in an iron kettle and heat until the resin softens; then add the lye, and stir thoroughly; now add four gallons of hot water, and boil until a little will mix with cold water and give a clear ambercolored liquid; add water to make up five gallons; keep this as a stock solution, and for use take one gallon of stock solution to twenty-five gallons of arsenate of lead spray mixture.

The flour-paste adhesive so successful in causing the sulfur, used in sulfur spraying for red spiders (Bulletin No. 154, California Experiment Station) to resist the action of the rain, will also answer well here. It is prepared as follows: Take one pound of wheat flour to one gallon of water. Place the flour in a box with a screen bottom (common wire window screening), and pour the water through it until all the flour has been washed into the receiving vessel. It will then be finely divided and free from lumps. The mixture should then be brought to the boiling point, being stirred constantly, thus forming a thin paste without lumps. Use four gallons of this paste to every one hundred gallons of water; run it through a strainer before adding to the spray mixture. 
thorough overshot and undershot applications. A special effort to wet the stem ends of the apples on the inside of the tree will doubtless prove beneficial.

The Fourth Spraying.-A reasonable interval would place this application about June 17th, and the arsenate of lead may be reduced to a minimum, or 1 pound to 50 gallons of water.

The Fifth Spraying.-About July 10th another spraying will be advisable, using 1 pound of lead arsenate to 50 gallons of water. This time considerable care should be taken to spray the inside of the tree and also to reach the stem ends of the apples.

The Sixth Spraying.-On August 1st the sixth application should be made as directed for the fifth.

The Seventh Spraying.-Another application is due about the 21st of August. As the later and more severe attack of worms is now becoming evident, the material should be increased, using about 2 pounds to 50 gallons of water. At this time great stress must be placed in wetting the stem ends of the apples under the leaf protections. The entire under surface of the fruit also needs wetting; this can only be accomplished by undershot spraying.

The Eighth Spraying.-On or about September 12th another application as directed for the seventh spraying should be made.

The Ninth Spraying.-During the first week in October another spraying should be given, using 2 pounds of lead arsenate to 50 gallons of water. This application should be followed by other sprayings every three weeks until the fruit is picked.

Results to be Expected from Spraying.-The great drawback which has militated against the complete success of spraying in the Pajaro Valley was the injuries to the trees from paris green and other arsenicals. These injuries made it necessary in most cases to abandon active spraying operations just at a time when the campaign should have been most energetically prosecuted.

The adoption of a safe insecticide will remove this difficulty, so that results comparable with those obtained elsewhere may confidently be expected. It should be remembered in this connection that even when spraying was abandoned about the middle of August, 1903, a control of 95 per cent was obtained in many orchards. Then conscientious work with lead arsenate may be expected to yield a control in the neighborhood of 95 to 98 per cent.

The Cost of Spraying.-Arsenate of lead spraying, figuring on the commercial lead at 15 cents per pound, will be nearly twice as expensive as paris green for the same sized tree. 
For the schedule just given, the lead for nine sprayings will cost $\$ 2.10$. This is to be diluted with 450 gallons of water and applied at the rate of five gallons per tree per application (the estimate is made for a full-bearing orchard), or forty-five gallons for the nine sprayings. This gives 21 cents as the cost of material per tree, and a fair estimate of the cost of application per gallon would be about one-quarter of a cent, which makes a total cost of 32 cents. 'This figure looks large, but it is desired to give an over, rather than an under estimate in making an approximate. Even considering the cost of 35 cents for the larger full-bearing trees, it is not more than half the net returns on a box of sound apples. So if the control expected is obtained, spraying at this figure will prove a very profitable investment.

Objections to Arsenical Spraying.-In every section where arsenical spraying for the codling-moth is practiced, the solid deposit left on the fruit probably gives rise to more or less criticism, but in practice this has not proved objectionable.

In other apple-growing sections this whitewash is carried to such an extent that the color of the fruit is obscured, but when the coating is wiped off the rind is found in as good, if not in a better, condition than that of the unsprayed product.

The poisonous effects of the arsenicals on persons eating the sprayed fruit while applying the wash might be imagined to be a serious objection to their use. In fact, however, no authentic case of poisoning has developed, and it may be further stated in this connection that minute quantities of arsenic have been proved to be harmless and are always to be found in the system.

With regard to the dangers arising from the application of the spray, this injury is least with good commercial lead arsenate because of its complete insolubility, which renders it impossible for the operators to absorb any poison through the pores of the skin. The manufacture of home-made lead arsenate might subject those in charge of that part of the operations to the danger of lead poisoning, but it is hardly probable that any one would remain at this work long enough to be affected.

\section{SUMMARY.}

It is recommended that paris green be discarded in all localities where its careful use has proved injurious to the trees.

Arsenate of lead has been found reliable as an insecticide as well as neutral toward vegetation, and its use is recommended.

During the coming season the growers are advised to use commercial lead arsenate, rather than attempt the production of the home-made article. 
Eight to ten sprayings are recommended to be applied, as indicated in the table below:

\begin{tabular}{|c|c|c|c|c|}
\hline \multirow{2}{*}{$\begin{array}{l}\text { Number of } \\
\text { Application. }\end{array}$} & \multirow{2}{*}{$\begin{array}{l}\text { Approximate } \\
\text { Date of } \\
\text { Spraying. }\end{array}$} & \multicolumn{2}{|c|}{$\begin{array}{l}\text { Amount of Material } \\
\text { to Use. }\end{array}$} & \multirow{2}{*}{ Method of Application. } \\
\hline & & $\begin{array}{l}\text { Arsenate of } \\
\text { Lead. }\end{array}$ & Water. & \\
\hline $1 \mathrm{st}$ & A pril 10 & $3 \mathrm{lbs}$. & 50 gals. & Overshot. \\
\hline $2 d$ & April 30 & 2 lbs. & 50 gals. & Over- and undershot. \\
\hline $3 d$ & May 17 & $1 \frac{1}{2} \mathrm{lbs}$ & 50 gals. & Over- and undershot; thor- \\
\hline 4 th & June 12 & $1 \mathrm{lb}$. & 50 gals. & Over- and undershot; thor- \\
\hline 5 th & July 10 & $1 \mathrm{lb}$ & 50 gals. & Over- and undershot; thor- \\
\hline 6 th & Aug. 1 & $1 \mathrm{lb}$. & 50 gals. & $\begin{array}{l}\text { ough inside spraying. } \\
\text { Over- and undershot; very } \\
\text { thorough inside spraying. }\end{array}$ \\
\hline 7 th & Aug. 21 & $2 \mathrm{lbs}$. & 50 gals. & $\begin{array}{l}\text { Over- and undershot; very } \\
\text { thorough inside spraying. }\end{array}$ \\
\hline 8 th & Sept. 12 & $2 \mathrm{lbs}$. & 50 gals. & $\begin{array}{l}\text { Over- and undershot; very } \\
\text { thorough inside spraving. }\end{array}$ \\
\hline \multicolumn{2}{|c|}{$\begin{array}{l}\text { Subsequent spraying: every } \\
\text { three weeks untilfruit is picked. }\end{array}$} & $\begin{array}{l}2 \text { lbs. } \\
1 \text { to } 2 \text { lbs. }\end{array}$ & $\begin{array}{l}50 \text { gals. } \\
50 \text { gals. }\end{array}$ & $\begin{array}{l}\text { Over- and undershot; very } \\
\text { thorough inside spraying. } \\
\text { Over- and undershot; very } \\
\text { thorough inside spraying. }\end{array}$ \\
\hline
\end{tabular}


